
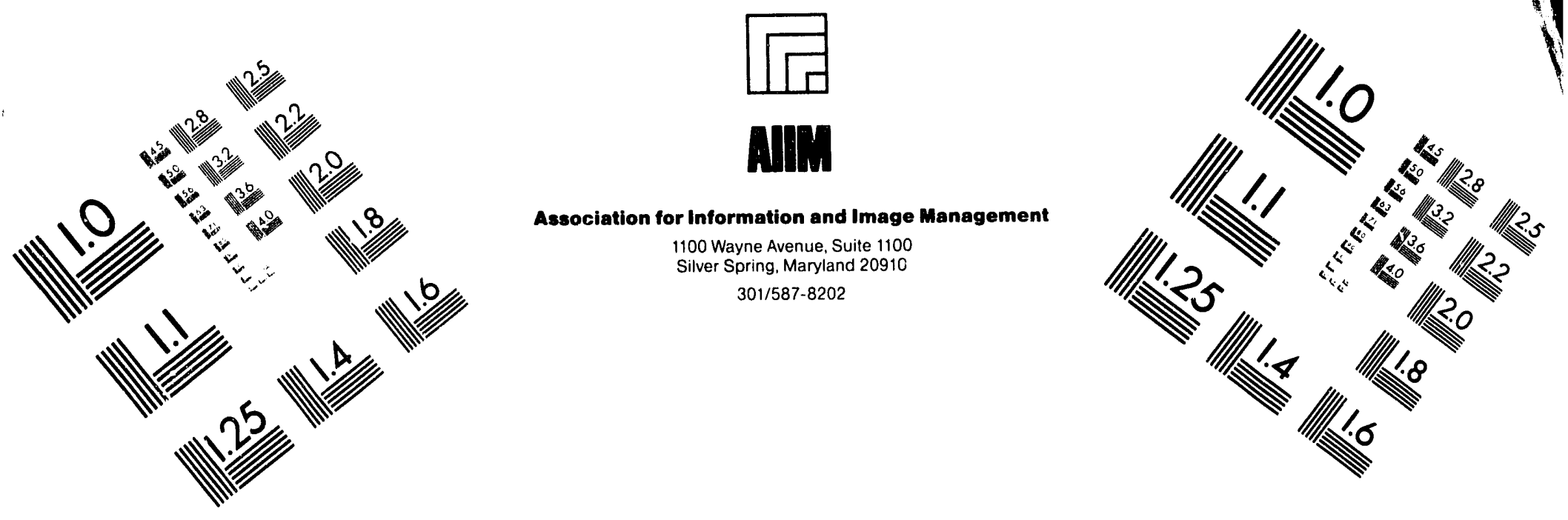

Centimeter

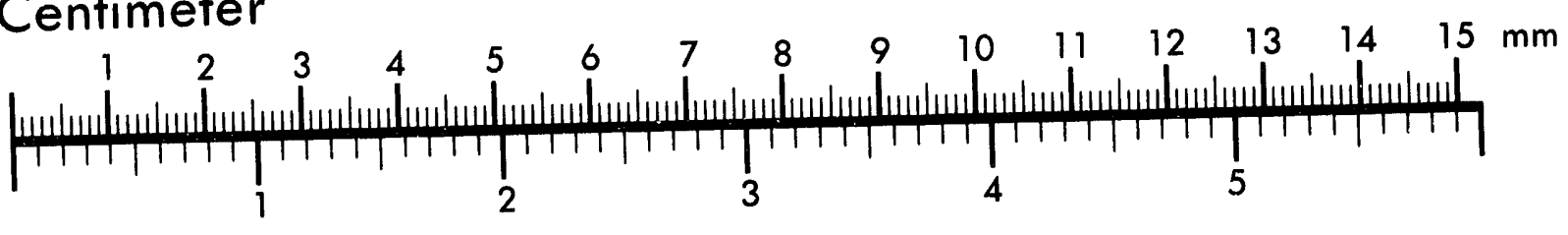

Inches
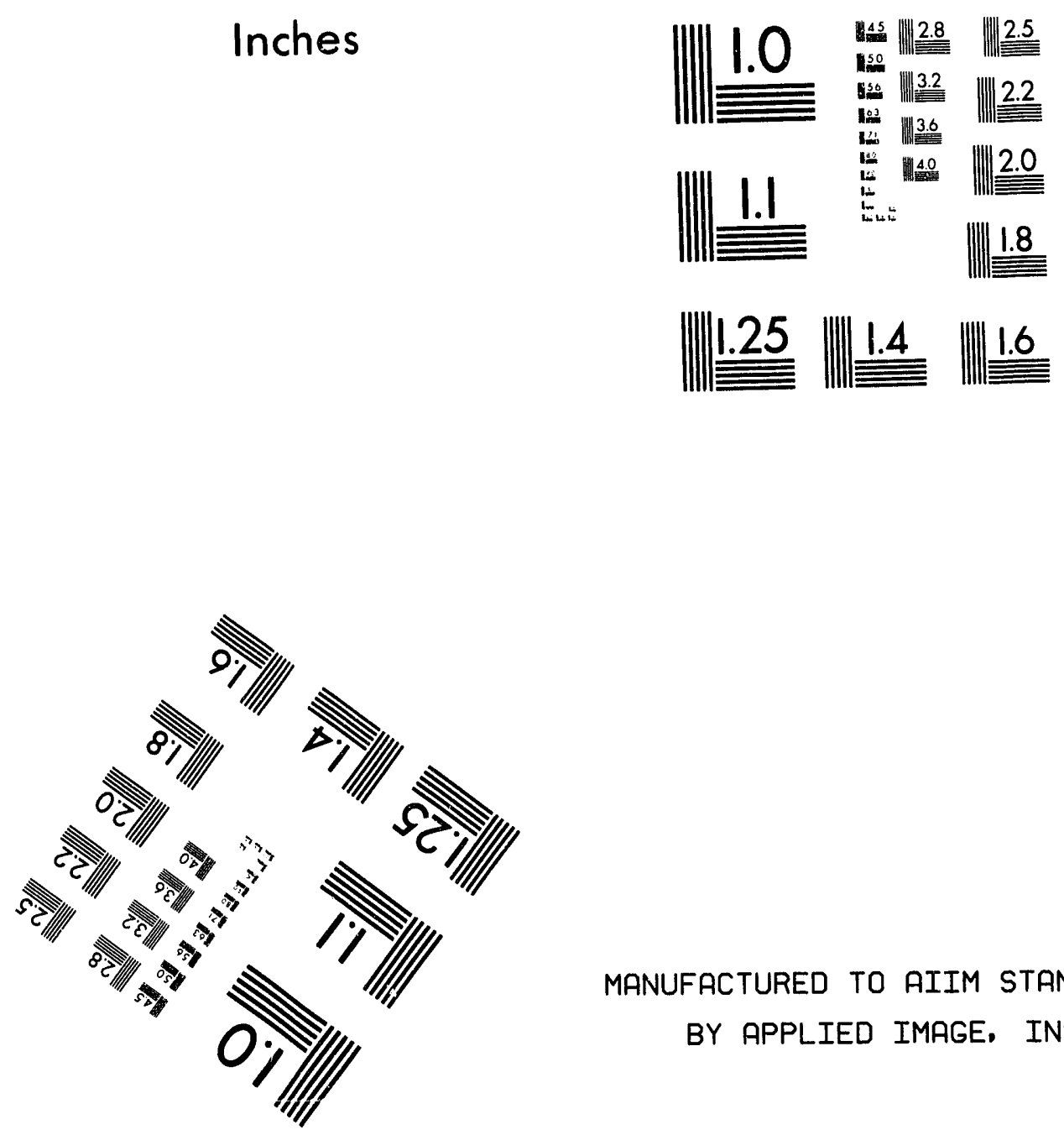

MANUFACTURED TO AIIM STANDARDS

BY APPLIED IMAGE, INC.

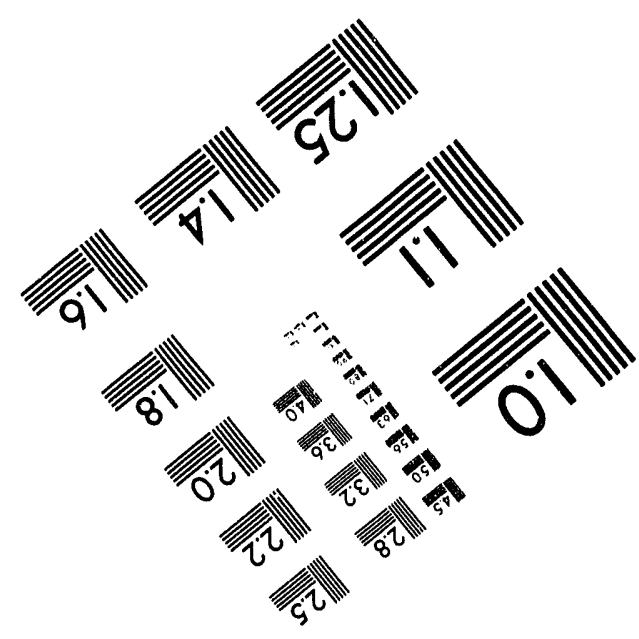



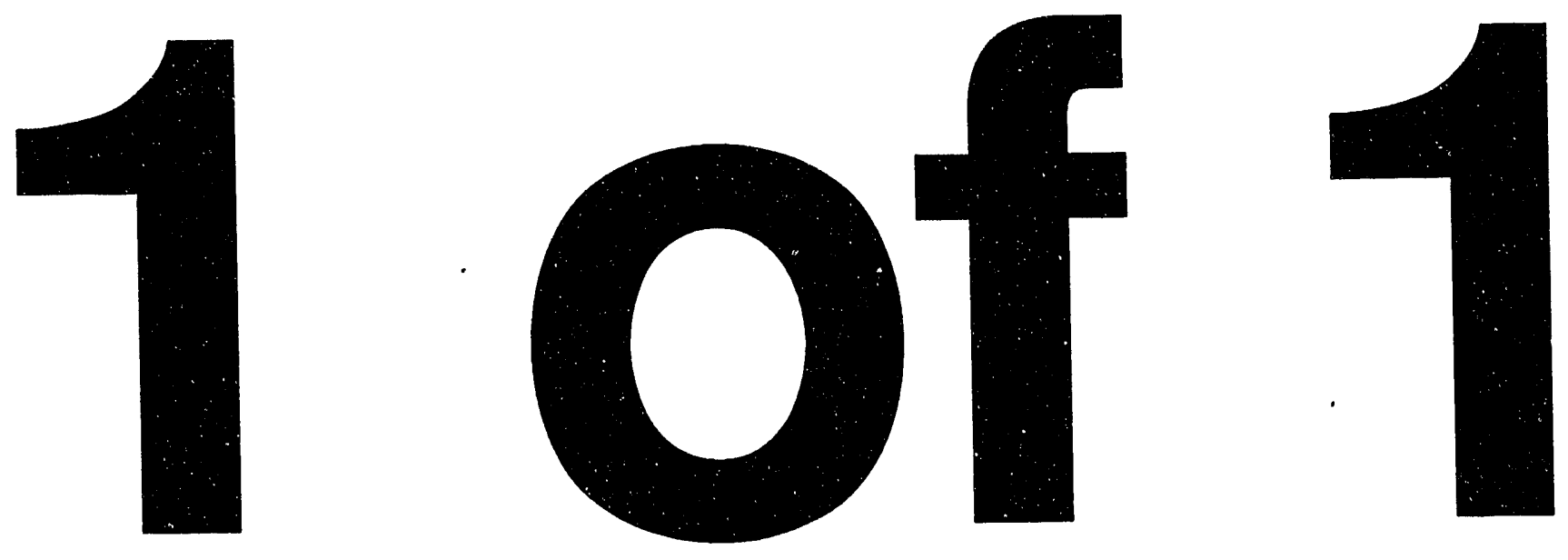


\title{
In Vivo Animal Models of Body Composition in Aging ${ }^{1}$
}

\author{
S. YASUMURA, ${ }^{*+} K$. JONES,* P. SPANNE,* G. SCHIDLOVSKY,*

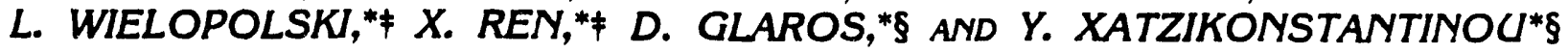 \\ "Brookhaven National Laboratory, "Upton, NY 11973, +State University of New York, Health Science \\ Center, Brooklyn, ¥State University of New York, Health Science Center, Stony Brook, and §University \\ of loannina, Greece
}

\begin{abstract}
We developed several techniques that provide data on body elemental composition from in vivo measurements in rats. These methods include total body potassium by whole-body counting of endogenous ${ }^{40} \mathrm{~K}$; total body calcium (TBCa), sodium and chloride by in vivo neutron activation analysis and total body phosphorus (TBP) and nitrogen (TBN) by photon activation analysis. These elements provide information on total body fat, total body protein and skeletal mass. Measurements were made in 6-, 12- and 24-month-old rats. TBN increased slightly between 6 and 12 months but was significantly lower by 24 months, indicating a substantial loss in total body protein. Working at the National Synchrotron Light Source, we studied rat femurs by computed microtomography (CMT), and the elemental profile of the femur cortex by synchrotronradiation induced X-ray emission (SF.IXE). Although there were no significant changes in TBCa and TBP, indices of skeletal mass, CMT revealed a marked increase in the size and number of cavities in the endosteal region of the fernur cortex with increasing age. The SRIXE analysis of this cortical bone revealed a parallel decrease in the endosteal $\mathrm{Ca} / \mathrm{P}$ ratio. Thus, there are major alterations in bone morphology and regional elemental composition despite only modest changes in total skeletal mass. J. Nutr. 000: 000-000, 1993.
\end{abstract}

\section{INDEXING KEY WORDS:}

- rat body composition - body protein microcomputed tomography of bone $\bullet X$ ray fuorescence of bone - neutron activation analysis

There have been many aging studies of specific organ systems or cell lines from animals, but there have been far fewer studies of whole body composition, and most of these have relied on carcass analysis end points. Over the past few years we developed a series of techniques to determine a number of body elements in vivo. Carcass analysis usually involves the sampling

$0022 \cdot 3166 / 93$ S3.00 c) 1993 American Institute of Nutrition. of small aliquots of homogenates from whole animals to determine the body elements chemically. Small inhomogeneities and extrapolation from microsample analyses to whole body estimates of chemical composition can lead to large errors. Also, homogenization of the whole animal and chemical analyses are very time consuming. In contrast, in vivo measurement is usually faster, and good accuracy and precision can be achieved by using size- and weight-matched phantom standards.

Whole body counting and in vivo neutron activation analysis have been used as major tools in human body composition studies for many years at Brookhaven National Laboratory (BNL) (Cohn et al. 1980, 1983, 1985). Less well known is the fact that we have conducted parallel in vivo body composition studies in rats. There are obvious experimental limitations when human subjects are involved. For example, the radiation dose to the patient must be low enough to meet the clinical research safety guidelines, whereas with rats, having relatively short lifespans, the radiation exposure need only be limited by doses that would affect the experimental outcome. Also, the use of animal models is the only practical way to achieve a sufficiently uniform population to be able to study one variable at a time without the confounding problems posed by multiple variable systems that are inherent in almost all clinical investigations.

\footnotetext{
1 Presented as part of a symposium: Aging and Body Composition: Technological Advances and Physiological Interrelationships, given at the 76th Annual Meeting of the Federation of American Societies for Experimental Biology, Anaheim, CA, April 7, 1992. This conference was sponsored by the American Institute of Nutrition. Guest editors for this symposium were Steven B. Heymsfield, M.D., Department of Medicine, Columbia University College of Physicians and Surgeons, New York, NY 10025, and Seiichi Yasumura, Ph.D., Deparment of Physiology, State University of New York, Healch Science Center, Brooklyn, NY, and Brookhaven National Laboratory, Upton, NY 11973.
}

Research supported by US DOE contract DE-ACO2-76CH00016.
001

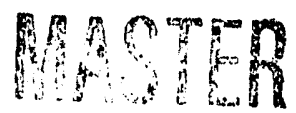

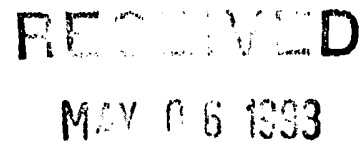

/ I12 C4092S\$\$99 10-23-92 16:11:18 LP: Nutrition Suppl1S39

DISIRIBUTION OF THIS DgCUMEAT is 


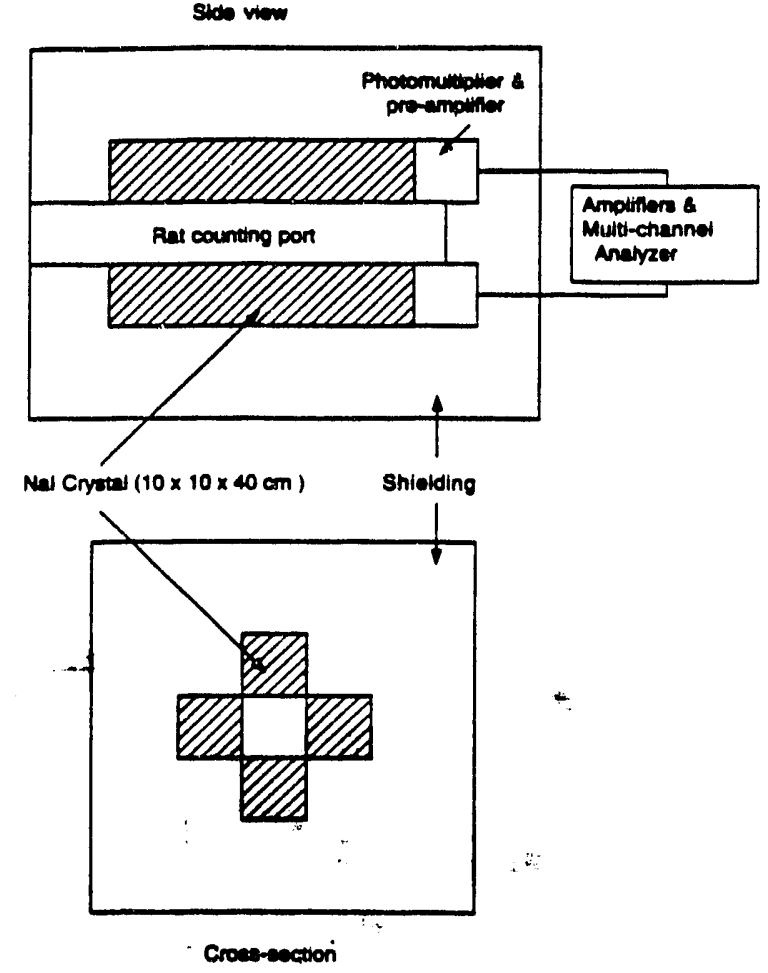

FIGURE 1 Diagram of the rat whole body counter. Four sodium iodide detectors, each $10 \times 10 \times 40 \mathrm{~cm}$, are arranged above, below and one on each side of the rat chamber. Standard electronics and a PC-based multichannel anaiyzer ( $\mathrm{Nu}$ cleus| were used for data collection and analysis.

\section{WHOLE BODY COUNTING}

Because rats are small, the absolute amount of each element of interest often falls below the detection limit of the instrumentation used in human studies. For example, the amount of potassium (TBK) in the body of a $70-\mathrm{kg}$ human may be about $130 \mathrm{~g}$; counting a person in the BNL whole body counter for 15 minutes will provide a precision of measurement of approximately $1.8 \%$ (Dilmanian et al. 1990). The task of measuring TBK in a $300-\mathrm{g}$ rat that is 230 times lighter than a 70 $\mathrm{kg}$ human requires a more sensitive counting system and/or longer counting times. This was achieved by using $4 \mathrm{Nal}$ detectors, each measuring $10 \times 10 \times 40$ $\mathrm{cm}$, by bringing each detector as close as possible to the animal and by arranging the detectors above, below and one on each side of the rat, a counting geometry that approximates a $4 \pi$ configuration (Fig. 1). Also, the detectors were surrounded by large amounts of shielding material, mostly lead, so the background counts are very low. With this system we can measure TBK in rats with a precision of $3 \%$ by counting each animal for 2 hours.

\section{IN VIVO NEUTRON ACTIVATION ANALYSIS}

To measure total body sodium (TBNa), chloride (TBCl) and calcium (TBCa) in rats, we constructed a neutron activation system (Fig. 2) using four Califor nium-252 sources, two placed on each side of the an imal activation chamber (Yasumura et al. 1987). The ${ }^{252} \mathrm{C}$ fopurces are housed in aluminum tubes that car be moved mechanically from a well-shielded storagt area to the activatiof position. Each tube contains twc $150-\mu \mathrm{g}{ }^{252} \mathrm{Cf}$ sources, giving a total of $600 \mu \mathrm{g}$ of ${ }^{252} \mathrm{Cj}$ in the system. The neutrons are partially moderated with water placed between the sources and the rat chamber; this gives a more uniform distribution of thermal neutron flux through the animal. Our procedure was to activate the rat for 5 minutes, then in 1 minute to transfer the rat from the activation facility to the counting system in the next room and then to count the rat for 15 minutes. The activation and counting systems are sufficiently well shielded so that there is no interference nor increase in the background counting rate due to the proximity of the ${ }^{252} \mathrm{Cf}$ sources to the counter. Bottle phantoms matched in size and weight for each set of rats are used for background corrections and standardization. To determine the background, the bottle is filled with water and the activation and counting procedures are carried out at the beginning and end of each series of animals, typically in the early morning and late afternoon. Standards containing known amounts of $\mathrm{Na}, \mathrm{Cl}$ and $\mathrm{Ca}$ are measured as single-element phantoms and as a mixture of all three elements.

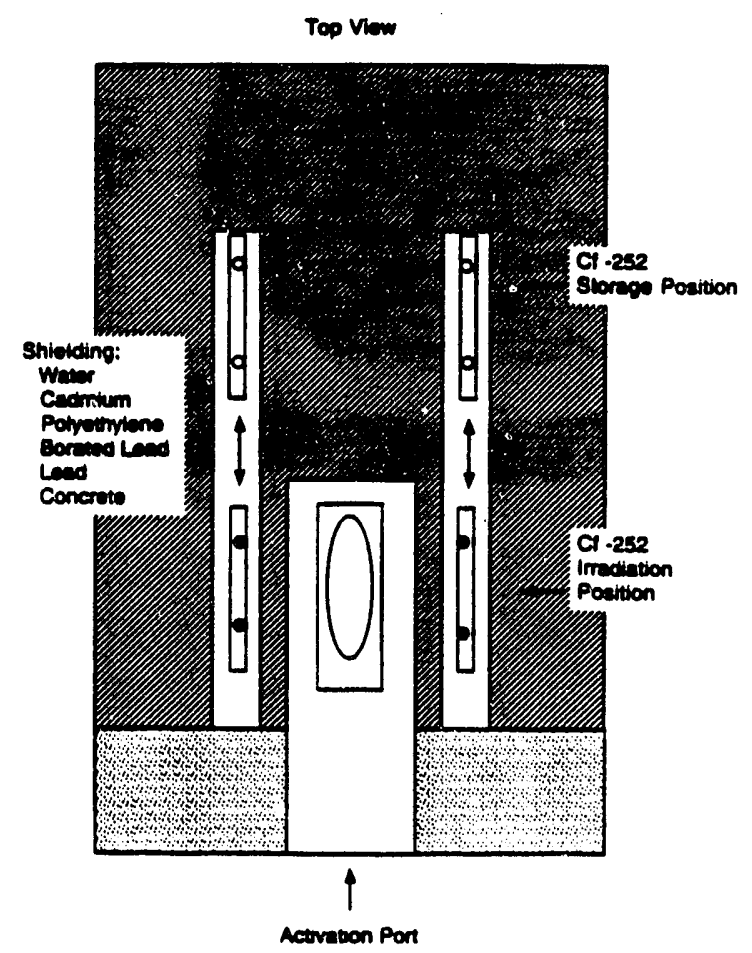

FIGURE 2 Top view schematic of the rat neutron-activation unit. Four $150-\mu \mathrm{g}{ }^{252} \mathrm{Cf}$ sources, two on each side of the midline, are moved mechanically from their storage locations to positions adjacent to the rat chamber during activation. 


\begin{tabular}{|c|c|c|c|c|}
\hline \multicolumn{5}{|c|}{$\begin{array}{l}\text { Photoniclear characteristics of the major elements } \\
\text { in the human body }\end{array}$} \\
\hline Element & $\begin{array}{c}\text { Percent of } \\
\text { body } \\
\text { weight }\end{array}$ & $\begin{array}{l}\text { Threshold } \\
\text { energy }\end{array}$ & $\begin{array}{c}\qquad \gamma, n \mid \\
\text { Half-life } \\
\text { (min) }\end{array}$ & $\begin{array}{c}\text { Daughter } \\
\text { emission } \\
\text { lines }(\mathrm{MeV}\end{array}$ \\
\hline 160 & 61.0 & 15.7 & 2.03 & 0.511 \\
\hline${ }^{12} \mathrm{C}$ & 23.0 & 18.7 & 20.40 & 0.511 \\
\hline${ }^{1} \mathrm{H}$ & 10.0 & - & - & - \\
\hline${ }^{14} \mathrm{~N}$ & 2.6 & 10.6 & 9.97 & 0.511 \\
\hline${ }^{40} \mathrm{Ca}$ & 1.4 & 15.6 & 0.015 & 0.511 \\
\hline${ }^{31 p} \mathrm{p}$ & 1.1 & 12.3 & 2.50 & $\begin{array}{l}0.511 \\
1.27(0.5 \%)\end{array}$ \\
\hline${ }^{32} \mathrm{~S}$ & 0.2 & 15.1 & 0.044 & $\begin{array}{l}0.511 \\
1.27(1.1 \%)\end{array}$ \\
\hline${ }^{39} \mathrm{~K}$ & 0.2 & 13.1 & 7.63 & $\begin{array}{l}0.511 \\
2.17(99 \%)\end{array}$ \\
\hline${ }^{23} \mathrm{Na}$ & 0.14 & 2.4 & $2.6 \mathrm{y}$ & $\begin{array}{l}0.511 \\
1.27(90 \%)\end{array}$ \\
\hline${ }^{35} \mathrm{Cl}$ & 0.12 & 12.5 & 32.2 & $\begin{array}{l}0.511 \\
1.17(9 \%) \\
2.14(25 \%) \\
3.32(9 \%)\end{array}$ \\
\hline
\end{tabular}

Note: with 15-MeV photons, N, P, K, Na and $\mathrm{Cl}$ can be activated; however, $\mathrm{K}, \mathrm{Na}$ and $\mathrm{Cl}$ contribute very little to the $511 \mathrm{keV}$ peak. Also, the amount of $\mathrm{K}, \mathrm{Na}$ and $\mathrm{Cl}$ in the body is so low that they fall below the sensitivity of this reaction.

\section{PHOTON ACTIVATION ANALYSIS}

Total body nitrogen (TBN) and phosphorus (TBP) in rats can be measured by photon-activation $(\gamma, n)$ analysis using high energy $X$-rays from a standard radiation therapy unit. The specific radionuclide(s) produced depends on the amount of the parent element in the body and on the reaction $(\gamma, n)$ energy threshold, as shown in Table 1 (Wielopolski et al. 1987). Most radionuclides resulting from this bremsstrahling irradiation are positron emitters. From the differences in energy thresholds and half-life of the radionuclide produced, in combination with known elemental tissue abundance, we can separate and quantify the dif-

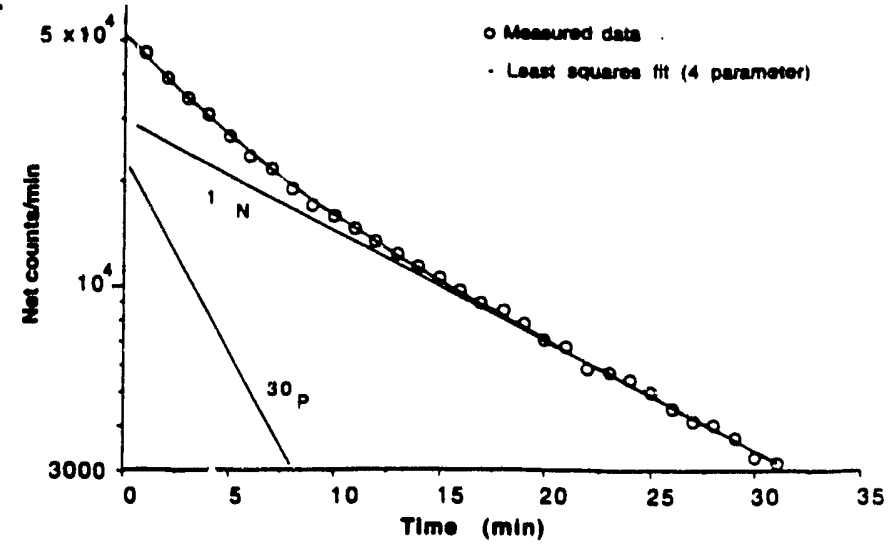

FIGURE 4 Curve of successive 30-second counts in the 511 peak over a 30 -minute collection. The curve is deconvoluted into its component parts, $\mathrm{N}$ and $\mathrm{P}$, by least-squares fitting.

ferent elements. For example, using the $15-\mathrm{MeV}$ radiation therapy unit (Varian), N, P, K, Na and $\mathrm{Cl}$ can be activated. However, the amount of $\mathrm{K}, \mathrm{Na}$ and $\mathrm{Cl}$ in the body is quite low, and these elements have very small cross-sections for bremsstrahling radiation, so the contribution of $\mathrm{K}, \mathrm{Na}$ and $\mathrm{Cl}$ activation products to the gamma spectrum is negligible. The remaining tissue elements that are activated by $15-\mathrm{MeV}$ photons have different half-lives: $N=9.97$ minutes and $P$ $=2.5$ minutes. Fig. 3 shows the combined counts in the $511-\mathrm{keV}$ window; a plot of these counts for each 30-second interval over 30 minutes is shown in Fig. 4. The measured decay curve is analyzed by a nonlinear least-squares method described by Bevington (1969), and the deconvoluted least-squares curves for $\mathrm{N}$ and $P$ are also shown in Fig. 4.

\section{ANIMAL STUDIES}

In a pilot study using rats from the Gerontology Research Center (National Institutes for Aging, NIH,

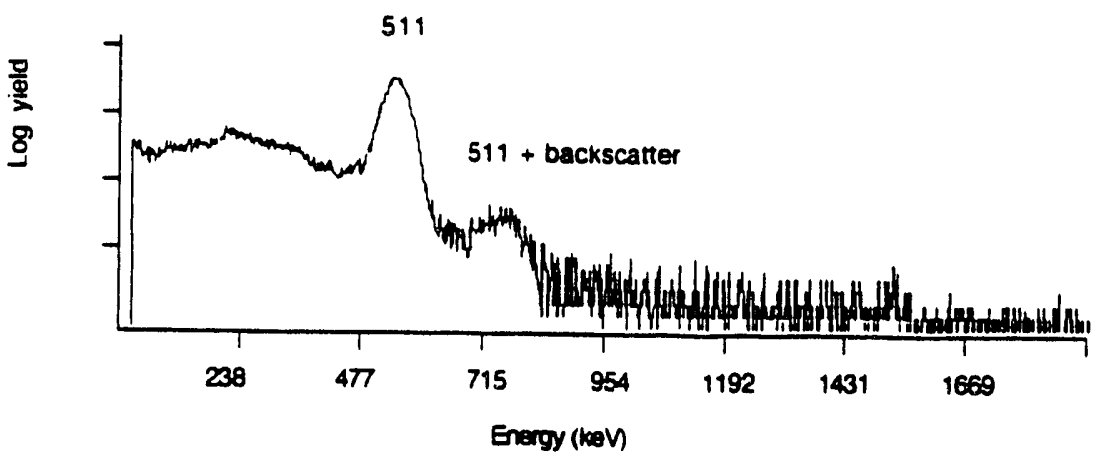

FIGURE 3 Gamma ray spectrum from a rat after photon activation with a Varian 15-MeV radiotherapy machine. The peak at $511 \mathrm{keV}$ is characteristic of positron emitters and represents counts from ${ }^{13} \mathrm{~N}$ and ${ }^{30} \mathrm{P}$. 
Baltimore) TBK, - $\mathrm{Ca},-\mathrm{Na},-\mathrm{Cl},-\mathrm{N}$ and $-\mathrm{P}$ were measured by the techniques described above. Three groups of rats were studied: at 6,12 and 24 months. The rats had been maintained ad libitum since weaning on the NIH open-formula rat chow (NIH-7) containing $1.2 \%$ $\mathrm{Ca}, 0.9 \% \mathrm{P}_{i}$ and $23.5 \%$ protein. TBK is a measure of body cell mass, and therefore is an index of metabolically active tissue. Body $\mathrm{K}$ decreased between 12 and 24 months of age (Table 2) but not in proportion to the loss in body weight, which would suggest that fat is lost at faster rate than lean tissue. Interestingly, despite the body weight loss, $\mathrm{TBNa}$ and $\mathrm{TBCl}$, indices of extracellular fluid volume, were slightly increased in 24-month-old animals. Table 2 also shows the TBCa values that are not significantly different between the three age groups. Because $99 \%$ of the body calcium is associated with bone, this finding indicates that skeletal mass does not change in proportion to the soft tissues (lean and fat) during aging.

When considered together with TBN, which is a direct measure of total protein mass in the body, TBK gives critical information about lean body mass and inferential estimates of muscle mass. Total body protein, as judged by TBN (Table 3), increases slightly between 6 and 12 months of age, but because of the marked increase in body weight during the same period, we conclude that most of the increase in weight can be ascribed to a gain in fat. Between 12 and 24 months, the rats' weight declined dramatically, but this decrease was extremely variable and rapid weight loss was usually followed by death within a month or two. For this strain of rat, 24 months is the age when there is approximately $50 \%$ mortality. Total body protein levels were significantly lower at 24 months compared with the 6 - or 12 -month-old rats. Because the 6-month-old rats were lighter than the 24-monthold rats, the difference in $\mathrm{N}$ is not just proportional to weight. This observation is consistent with the expected decline in lean body mass, particularly skeletal muscle loss, associated with very old age.

Table 3 also shows our data on phosphorus. Because more than $85 \%$ of the body phosphorus is in bone, like TBCa, it is a good index of skeletal mass. TBP did not change significantly with age, similar to the pattern noted with TBCa.

\section{TABLE 3}

Total body phosphorw (TBP) and nitrogen (TBN) measured by photon activetion analysis in male rasts

\begin{tabular}{rccc}
\hline Age & Bodywt. & TBP & TBN \\
\hline (mo) & (g) & (g) & (g) \\
6 & $424 \pm 29$ & $3.76 \pm 0.16$ & $: 8.0=1.1$ \\
12 & $578 \pm 35$ & $4.15 \pm 0.33$ & $19.7 \pm 1.2$ \\
24 & $479 \pm 24$ & $3.78 \pm 0.06$ & $156 \pm 0.0$ \\
\hline
\end{tabular}

Four animais per group. Values are means $\pm S D$.

\section{COMPUTED MICROTOMOGRAPHY OF THE FEMUR}

In contrast to the dramatic decrease in the $7 \mathrm{BN}$ witl age, changes in the skeletal mass, judged by TBCa anc TBP (Table 3) as noted above, were modest; despit. changes in body weight, skeletal mass remained rela tively stable. However, on closer inspection of the bone, we saw dramatic changes in the aging skeleton At autopsy, the femurs from each rat were dissected cleaned and prepared for computed microtomography (CMT) using an X-ray beam line at the BNL National Synchrotron Light Source (Spanne 1987). There is nc particular advantage in using CMT over conventiona! histological methods once the animal is dead, but CMT can also be used in the living but anesthetized animal by clamping its leg in a fixed position on the micromanipulator stage before placing the unit in the X-ray beam line assembly. Thus, by using CMT, sequential changes in bone morphology can be studied in vivo in the same animal. The tomographic results clearly show that there is significant endosteal erosion with resorption cavities that increase in size between 6, 12 and 24 months of age (Fig. 5, A-C). These changes are similar to those reported by Kiebzak et al (1988) and are reminiscent of changes that are seen in human subjects during aging (Parfitt 1984). The resorption cavities eventually become so large that they colalesce, increasing the diameter of the medullary space. There is a decrease in the thickness of the femoral cortex but an increase in the cross-sectional circumference and the diameter of the medullary space. Despite these

TABLE 2

Total body potasoium (TBK), sodium (TBNa), chloride (TBCl) and calcium (TBCa) measured by whole body counting and neutron activation analysis in male rats

\begin{tabular}{rccccc}
\hline Age & Body we & TBK & TBNa & TBCl & TBCJ \\
\hline (mol & (g) & (g) & (g) & (g) & (g) \\
& & & & & \\
6 & $550 \pm 21$ & $1.31=0.12$ & $0.53 \pm 0.05$ & $0.55 \pm 0.04$ & $6.31 \pm 0.66$ \\
12 & $616 \pm 47$ & $1.34 \pm 0.18$ & $0.54 \pm 0.07$ & $0.59 \pm 0.03$ & $0.83 \pm 0.25$ \\
24 & $499 \pm 57$ & $1.14 \pm 0.14$ & $0.60 \pm 0.04$ & 6.07 & 0.35 \\
\hline
\end{tabular}

Five rats per group. Values are means $\pm S D$.

/ 112 C4092SSS99 10.23-92 16:11:18 LP: Nutrition Suppl1S39 


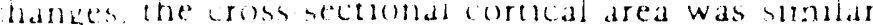
In the remurs trom all three dge groups sugkesting that there must have beet seme merease in permeteal
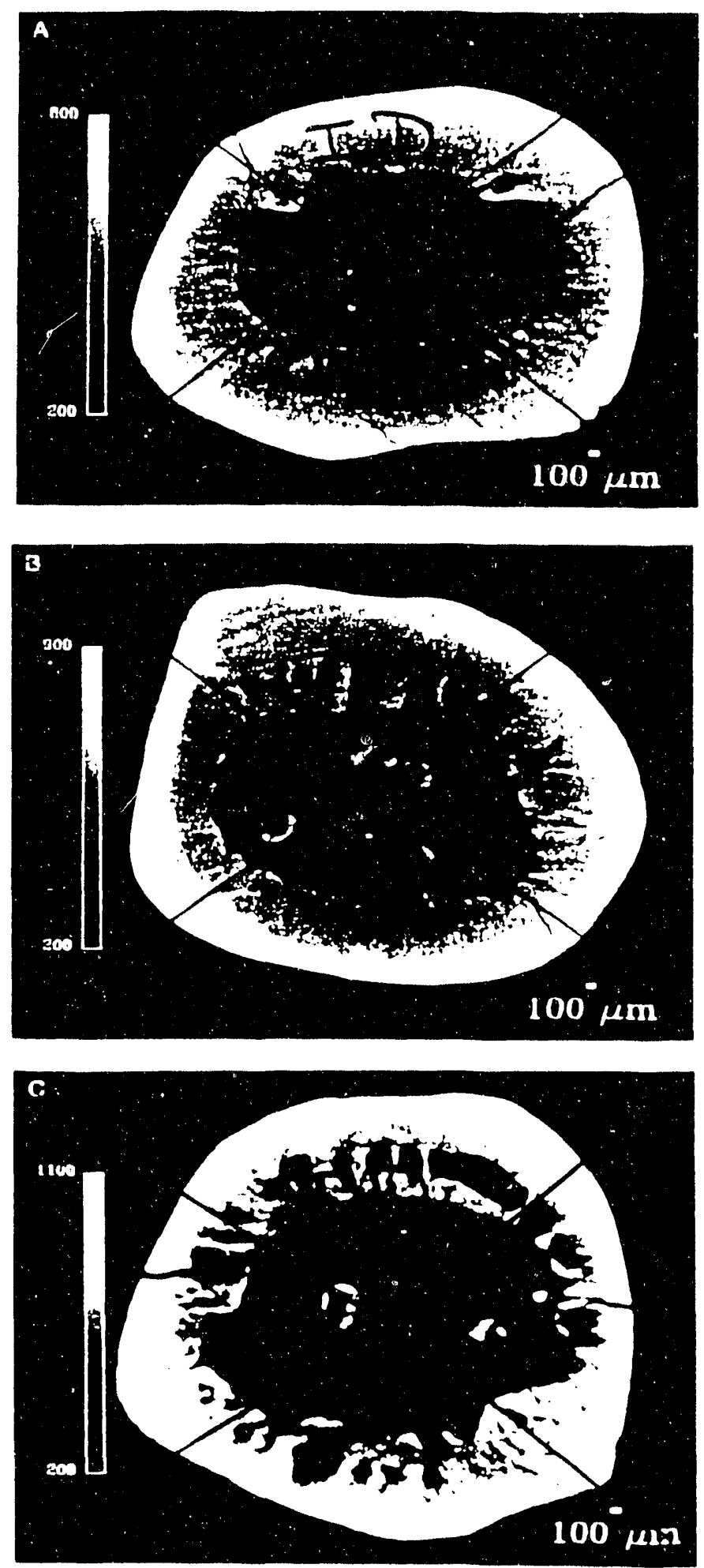

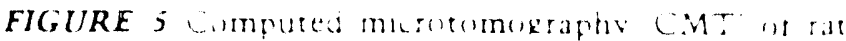
remugh at mlushatt tor male iats if ntterent age $A$ A

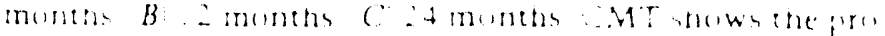

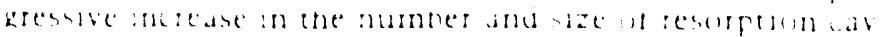
itie.

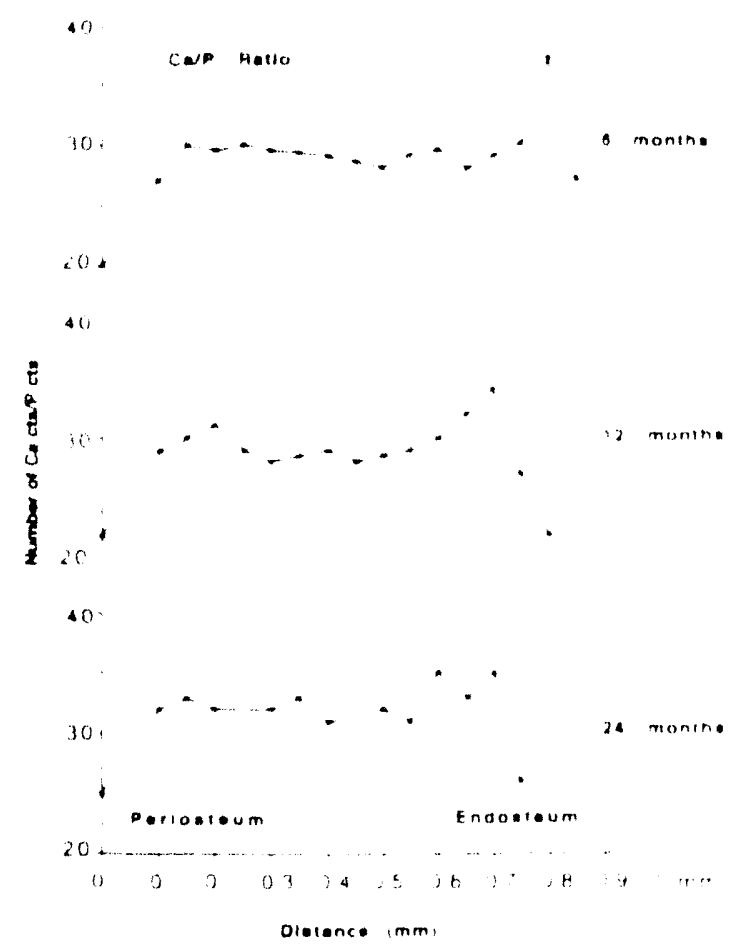

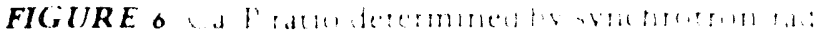

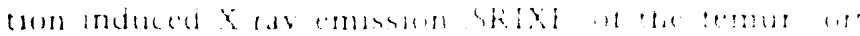

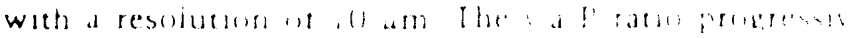

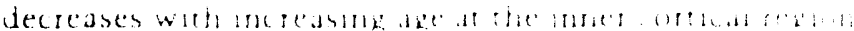
the bune

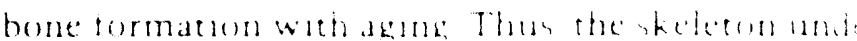
goes malor changes durng semescerse but the changes are note replected by changes at smilat ind.

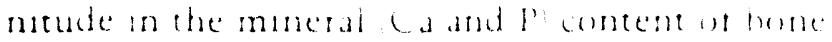

\section{$X$-RAY FLUORESCENCE OF CORTICAL BONE}

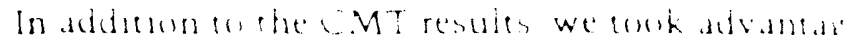

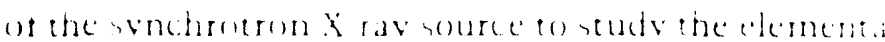

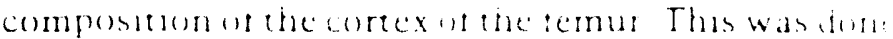

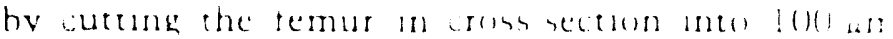
sleces and measurang the elemental compostenon en the temur eortex by senchroton radiaten anduced $X$ ra: emissun SRIXE Junes et al loke log() The ele mental prente was determaned on exeral repreenta

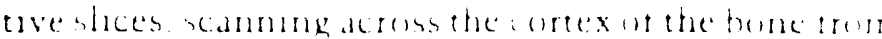

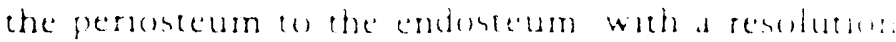

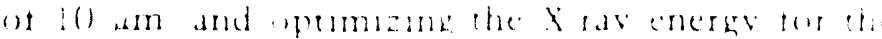

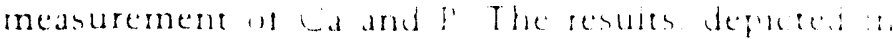

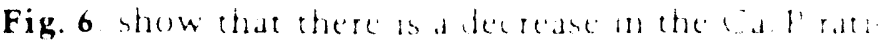

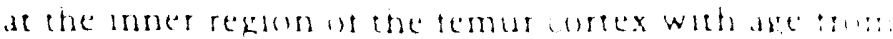

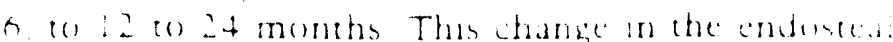

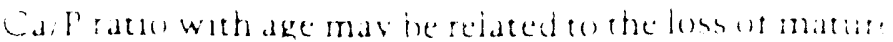

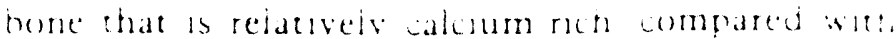
che outer surtace of the cerrex where acew heme th hemb 
laid down. A low $\mathrm{Ca} / \mathrm{P}$ ratio is more typical of immature bone, where crystal (hydroxyapatite) size is relatively small compared with mature bone. These results demonstrate that there is a change in the morphology and regional elemental composition of the skeleton with age.

In summary, we have developed a series of techniques for the in vivo measurement of body elemental composition in rats. These techniques are suitable for a variety of studies where the effect of treatment can be studied longitudinally because the in vivo measurements can be repeated as often as necessary in the same animals. In addition, a more detailed picture of bone can be obtained by CMT, and at autopsy, by using SRIXE for the multielemental analysis of cortical bone.

\section{LITERATURE CITED}

Bevington, P. R. (1969) Data Reduction and Error Analysis for the Physical Sciences. McGraw Hill, New York.

Cohn, S. H., Vartsky, D., Yasumura, S., Sawitsky, A., Zanzi, I., Vaswani, A. \& Ellis, K. J. (1980) Compartmental body composition based on total body nitrogen, potassium and calcium. Am. J. Physiol. 239: E524-E530.

Cohn, S. H., Vartsky, D., Yasumura, S., Vaswani, A. N. \& Ellis, K. I. (1983) Indexes of body cell mass: nitrogen versus potassium. Am. I. Physiol. 244: E305-E310.

Cohn, S. H., Vaswani, A., Yasumura, S., Yuen, K. \& Ellis, K. J. (1985) Assessment of cellular mass and lean body mass by non-invasive nuclear techniques. J. Lab. Clin. Med. 105: 305-311.
Dilmanian, F. A., Weber, D. A., Yasumura, S., Kamen, Y., Lidofsk L., Heymsfield, S. B., Pierson, R. N., Ir., Wang, J., Kehayias, J. \& Ellis, K. J. (1990) Performance of the delayed-and promf gamma neutron activation systems at Brookhaven National La oratory. In: Advances in In Vivo Body Composition Studi. (Yasumura, S., Harrison, J. E., McNeill, K. G., Woodhead, A. I \& Dilmanian, F. A., eds.), pp. 309-315, Plenum Press, New Yor. Jones, K.W. \& Gordon, B. M. (1989) Trace element determin. tions with synchrotron-induced $x$-ray emission. Anal. Chem. 6 $341 \mathrm{~A}$.

Jones, K. W., Schidlovsky, G., Burger, D. E., Milder, F. L. \& Hu, F (1990) Distribution of lead in human bone: synchrotron $x-r a$ microscope measurements. In: Advances in In Vivo Body Com position Studies (Yasumura, S., Harrison, I. E., McNeill, K. G Woodhead, A. D. \& Dilmanian, F. A. eds.l, pp. 281-286, Plenun Press, New York.

Kiebzak, G. M., Smith, R., Gundberg, C. C., Howe, J. C. \& Sacktor B. (1988) Bone status of senescent male rats: chemical, mor phometric, and mechanical analysis. J. Bone Miner. Res. 3: 37 45.

Parfitt, A.M. (1984) Age-related structural changes in trabecula: and cortical bone: cellular mechanisms and biomechanical con sequences. Calcif. Tissue Int. 36: S123-S128.

Spanne, P. (1987) Computerized microtomography using syn chrotron radiation from the NSLS. Nuc. Instr. \& Methods Phys Res. B24/25: 1063-1067.

Wielopolski, L., Meek, A. G., Moskowicz, M. \& Cohn, S. H. (1987! $(\gamma, \mathrm{n})$ Activation of cancer patients. J. Radioanal. Nucl. Chem. 114: $187-193$

Yasumura, S., Kiebzak, G. M., Ellis, K. I., LoMonte, A. F., Zhang, R., Yuen, K. \& Cohn, S. H. (1987) Body composition studies in aging rats. In: In Vivo Body Composition Studies (Ellis, K. J., Yasumura, S. \& Morgan, W. D., eds.l, pp. 118-122, The Instutute of Physical Sciences in Medicine, London.

\section{DISCLAIMER}

This report was prepared as an account of work sponsored by an agency of the United States Government. Neither the United States Gnvernment nor any agency thereof, nor any of their employees, makes any warranty, express or implied, or assumes any legal liability or responsibility for the accuracy, completeness, or usefulness of any information, apparatus, product, or process disclosed, or represents that its use would not infringe privately owned rights. Reference herein to any specific commercial product, process, or service by trade name, trademark, manufacturer, or otherwise does not necessarily constitute or imply its endorsement, recommendation, or favoring by the United States Government or any agency thereof. The views and opinions of authors expressed herein do not necessarily state or reflect those of the United States Government or any agency thereof. 

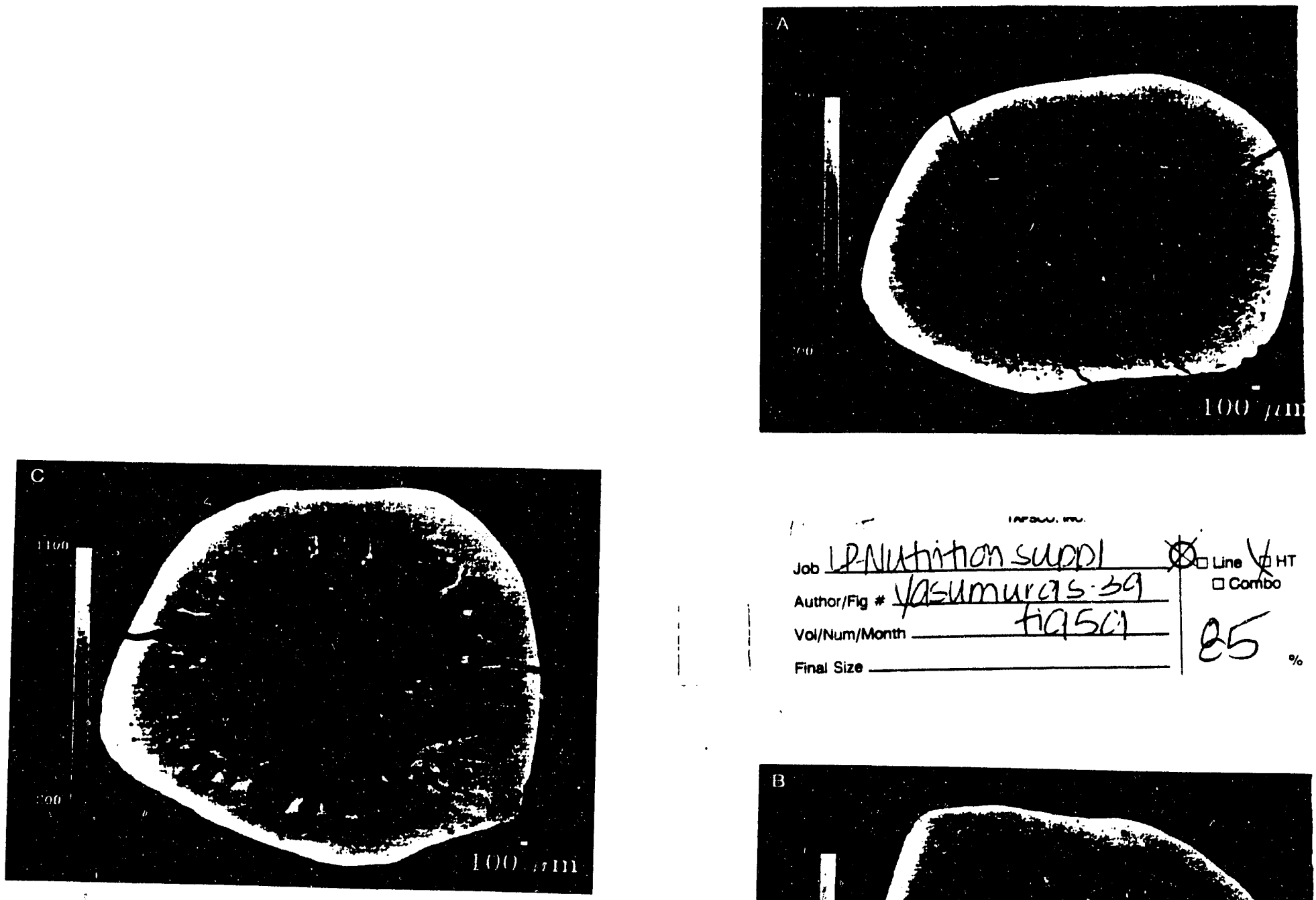

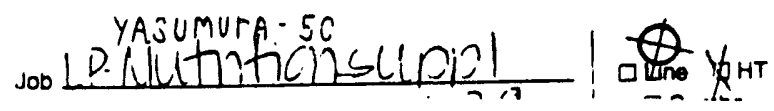

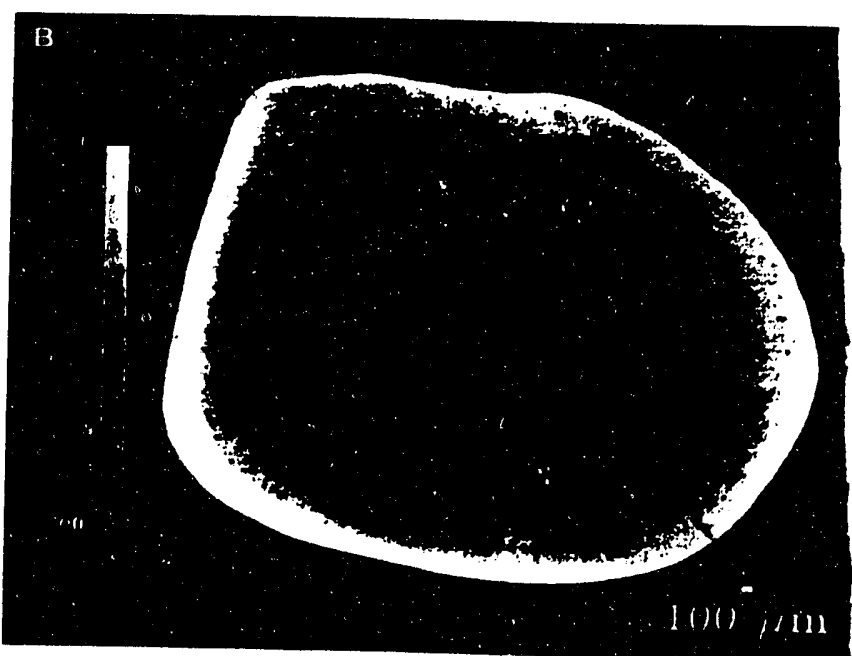

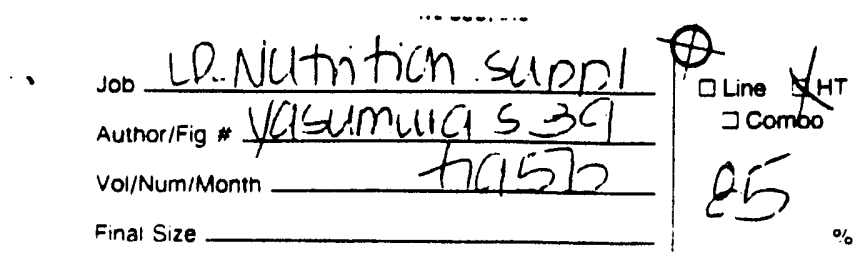



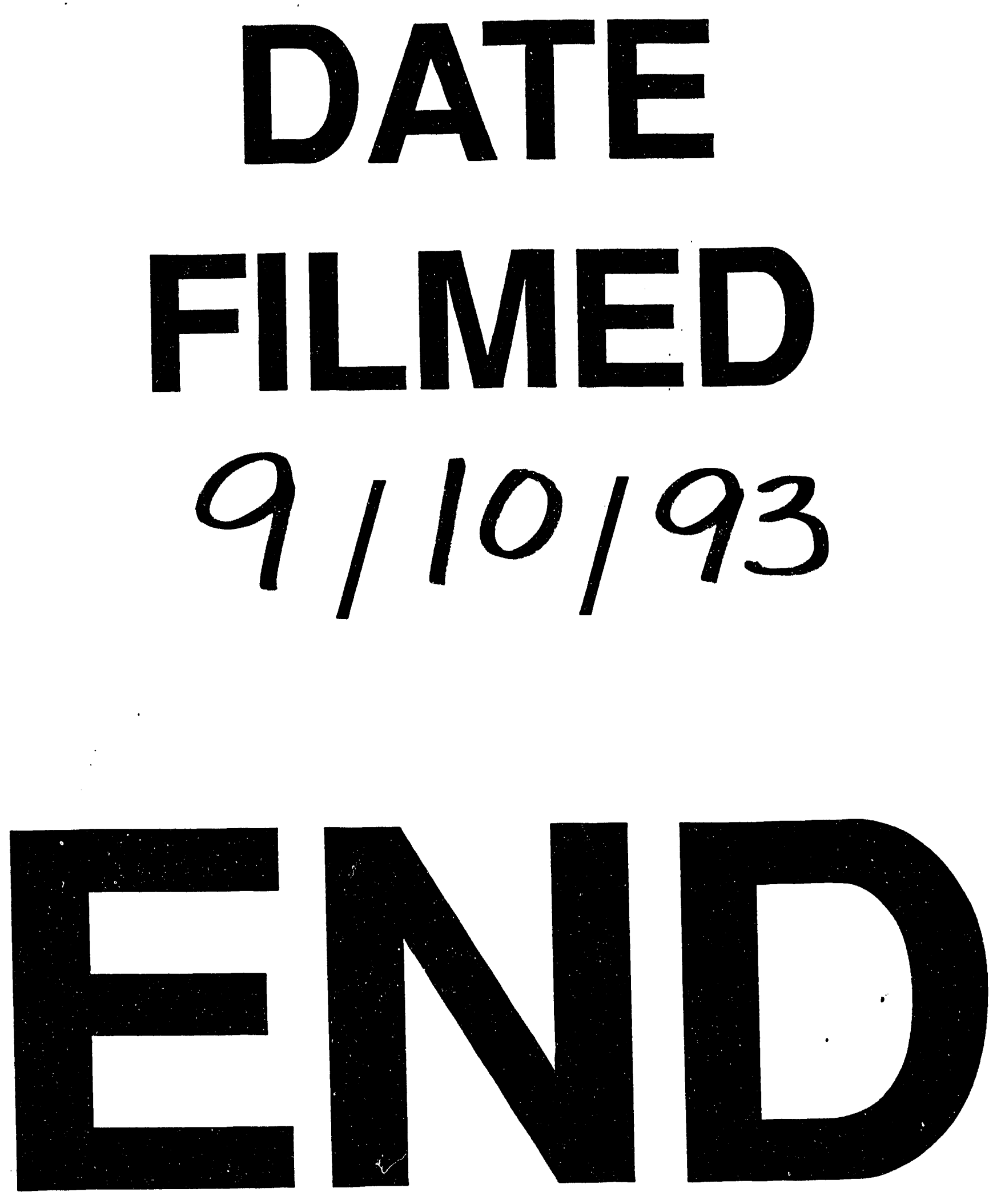
